\title{
Pseudepigraphy and the Petrine school: Spirit and tradition in 1 and 2 Peter and Jude
}

\author{
Patrick Chatelion Counet (Radboud University, Nijmegen) ${ }^{*}$ \\ Research Associate: Department of New Testament Studies \\ University of Pretoria
}

\begin{abstract}
This article identifies four "patterns of religion" (E P Sanders) in the pseudepigraphic letters of Peter and Jude in order to support the hypothesis of a "Petrine school" ( $\mathrm{J} \mathrm{H}$ Elliott). The first pattern that connects the letters is a Geisttradition (K Aland), guaranteeing continuity of tradition. The second is the interrelationship between faith and ethics (fides quae and fides qua). The combination of sanctification and eschatology is a third pattern connecting the three documents. Finally, two florilegia can be identified (one from the Old Testament and apocrypha, and one from the chokmatic tradition), suggesting a fourth pattern: a warning against ungodliness and infidelity. The existence of a Petrine group could represent a preliminary stage of subsequent Early Catholicism.
\end{abstract}

\section{INTRODUCTION}

In his article on the phenomenon of pseudepigraphy in early Christianity Kurt Aland points out that the Didache has been received as the Teaching of the Twelve Apostles, since the document was regarded as "the written version of what hitherto had been delivered at any congregational meeting" (Aland 1969:44).

By this Aland thinks that pseudepigraphy is not an isolated or individual phenomenon, but is backed by broader legitimation. His claim that "the Spirit himself was the real author" (Aland 1969:45) was subsequently criticised. Horst Balz maintains that, while the deutero-Pauline authors undoubtedly wrote in the spirit of the tradition and with apostolic normativeness, that was not the same as legitimation by the Holy Spirit of Kúpıos 'Inooûs (Balz

\footnotetext{
* Dr Patrick Chatelion Counet (PhD in Biblical Theology), lecturer of the New Testament at the Radboud University Nijmegen (The Netherlands), is a research associate of Prof Dr Andries $G$ van Aarde, Faculty of Theology, University of Pretoria.
} 


\section{Pseudepigraphy and the Petrine school}

1969:419f). Spirit-inspired authors chose anonymity, not pseudepigraphy, Balz believes, because the latter implied affiliation with tradition instead of the Spirit of Christ. In response to his critics Aland posited that pseudepigraphic writings like 2 Timothy and 2 Peter explicitly placed themselves in a Geisttradition: "Wer der Christenheit jener Zeit allgemeingültige Weisungen gibt, tut das aus dem Heiligen Geist, er ist nur die Feder, die vom Geist bewegt wird" (Aland 1980:137).

This raises two questions. Firstly, does Aland's notion of a shift from spoken to written messages - from congregational meetings to pseudepigraphic texts - not also imply the idea of collective authorship? Secondly, what does a Geisttradition mean for pseudepigraphic documents? This article deals with both questions with a view to a hypothesis of a Petrine school and the origin of 1 and 2 Peter and Jude.

\section{PSEUDEPIGRAPHY: A COMMUNAL ACTIVITY}

Until recently scholars were quick to assert that pseudepigraphy had nothing to do with fraud or the spuriousness of documents but was a commonly accepted phenomenon: their recipients recognised them as written in the style and the spirit of those purporting to be the authors (Harrison 1921:12). The current debate on pseudepigraphy also raises the issue of deliberate forgeries (Brox 1975:21-24). Donelson (1986:16) refers to "deceptive pseudepigraphy": "in Christian circles pseudonimity was considered a dishonorable device and if discovered, the document was rejected and the author, if known, was excoriated."

With the emergence of the great libraries of antiquity came a need for documents by famous authors and a strong temptation to produce forgeries. Religious pseudepigrapha were an exception; they were not meant to deceive but were looking for authority (Speyer 1977:195-263). Metzger (1972) identifies eight motives, three of which are negative (financial gain, pure malice, forgery), two are positive (love and respect to honour a revered teacher or school, modesty), and three are neutral (dramatic motives [speeches attributed to orators], accidents in copying, and anonymous writings attributed to important figures in antiquity).

The pseudepigraphic writings in the New Testament are mainly letters. No doubt the pursuit of authority was part of the motive for 1 and 2 Peter and Jude.

Another important insight in current research into pseudepigraphy is the influence of schools (Donalson 1986:10f and 23-42). In the case of New Testament pseudepigrapha it is usually assumed that a single (unknown) 
author was responsible for both the contents of the letter and the choice of a pseudepigraphic title. Even Aland (1980:132), writing about a Geisttradition, assumes that the Geist resided in the mind and the pen of a single author. On the other hand one should ask oneself whether the responsibility of signing letters pseudepigraphically - with prominent names such as Peter, Paul, James, Jude - did not in fact require a broader base. Maybe one should actually turn the question around: maybe there could be no pseudepigraphy without the legitimation of a community, group or school. In the case of literary (nonreligious) pseudepigrapha there is a far earlier assumption that these were school productions as a literary exercise to learn to write in the style of the Pythagoreans, Cynics, Stoics or Neo-Platonists (Speyer 1977:201ff). Armin Baum refers to Apostelschulen; to indicate the pseudepigraphic authorship of the documents produced by these schools Baum uses the Hebrew concept of "corporate personality" - a single prophet or writer acting on behalf of a whole community. He borrows this concept of a corporate personality from D Russell and H Robinson.(Baum 2001:61ff and 65-68).

Considering the "catholic" nature of the two Petrine letters and that of Jude - their intention to address "all" Christians (Bigg [1901] 1987:1) - there is some reason to assume that the pseudepigraphic choice was supported by communal legitimation. It is hardly conceivable that the name of Peter or Jude could be attached to a letter arbitrarily. The catholic nature of the letters is evident partly in the universal salutations - 1 Peter 1:1, while addressing large parts of Asia Minor, is still the most specific, 2 Peter 1:1 is addressed to "those who have obtained a faith of equal standing with ours", and Jude 2 to "those who are called" - but also and more particularly in the contents and structure of the letters. Charles Bigg already remarked about Jude: "His tone is that of a bishop of the fourth century ... men who used such phrases believed passionately in a creed" (Bigg [1901] 1987:325). To my mind his comment applies equally to the two Petrine letters. The way all three these letters stress tradition and Scripture, with reminders of the prophets, of a faith handed down over many generations, of the inspiration of great men - also in regard to exegesis - leads one to assume a central doctrinal authority. The concern is to uphold a common scriptural and exegetic tradition.

Initially this centre was in Jerusalem (see Ac 15; GI 1:18f) where James, Cephas and John were the pillars (GI 2:9). As Paul describes in Galatians 2:12, they had "certain men", their fellow workers, who visited other congregations. This centre most probably had its counterparts in Antioch, Rome, possibly in Alexandria as well; nowadays it is almost undisputed that the Johannine congregation in Ephesus was such a centre (Brown 1979:67; Van Tilborg 1996:3f). These centres maintained contact with each other, as 


\section{Pseudepigraphy and the Petrine school}

witness Acts 15:22-32. Here we are told how "it seemed good, with the whole

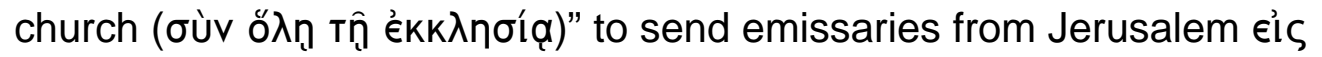

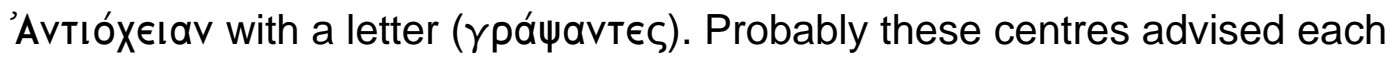
other on the content, theology and possible pseudonimity of documents.

When it comes to this phenomenon current exegesis too readily assumes that these were one-author efforts. It overlooks the fact that even the authentic Pauline letters were all written in conjunction with fellow workers and friends. ${ }^{1}$ Paul used, if not a church or a school, at least a gathering or thinktank. Schmidt argues that being co-signatories to letters is not the same as co-authorship (Schmidt 2003:55-60). Partly for this reason it seems justified to regard the pseudepigraphic documents 1 and 2 Peter and Jude as communal efforts - at any rate in the sense that they were written at the behest of missionaries, presbyters or other congregational representatives. In this sense as early as Brox (1975:111f), who toyed with the notion of "Schule" in regard to the figure of Peter: "... die urchristliche Falsa der Name ... [war] durch konkrete Traditionszusammenhänge einer bestimmten Theologie, eines kirchlichen Milieus mit einer individuellen historischen (apostolischen) Gestalt festgelegt."

The writers may have availed themselves of congregational meetings in their church (considering $1 \mathrm{Pt}$ 5:13, probably Rome), who legitimised the contents and pseudepigraphic choice of the letter. That would mean that the first readers of 1 and 2 Peter and Jude were not the recipient congregations, but the community (Rome) where the authors had their Sitz im Leben. There is growing consensus that this congregation should be referred to as the Petrine school (see section 2).

What Aland calls a Geisttradition - and the question under consideration in this article is whether the Petrine school had such a tradition - is termed "pattern of religion" by E P Sanders. By this he means "[t]he description of how a religion is perceived by its adherents to function ... of how getting in and staying in are understood (...) it includes the logical beginning-point of the religious life as well as its end, and it includes the steps in between" (Sanders 1977:17). The patterns of thought and understanding that link the three letters and form the basis of a Petrine school are the following:

\footnotetext{
${ }^{1}$ Paul wrote 1 Thessalonians with Silvanus and Timothy (1 Th 1:1), 1 Corinthians with Sosthenes (1 Cor 1:1), 2 Corinthians with Timothy (2 Cor 1:1), Philippians again with Timothy (Phlp 1:1), Galatians "with all the brethren who are with me" (GI 1:2; also see 6:11), and even the short letter to Philemon is legitimised by Timothy as co-author (Phlm 1:1). The sole exception is Romans, although here, too, Paul refers to "Timothy, my fellow worker" and Tertius refers to himself as the (actual) writer (Rm 16:21f).
} 
- adherence to tradition (1 Pt 1:10-12; 2 Pt 1:12, 3:2; Jude 3, 17);

- appointment of an authoritative body to interpret Scripture (1 Pt 1:12; 2 Pt 1:20f; Jude 3, 19);

- common eschatological expectation (passim);

- florilegium (A): paradigms from the Old Testament and the apocrypha of infidelity and apostasy, ảoéßeı (passim);

- florilegium (B): lists of quotations from the chokmatic tradition (passim).

If one wants to assign Jude and Peter a historical role in this church, it would be that of ghostwriters or implied authors rather than actual writers. Bauckham (1983:161) states that the sense in which 1 and 2 Peter both derive from a "Petrine circle" can only be that both were sent out by the leaders of the Roman church, who regarded Peter as their most authoritative member, present or past.

Quite conceivably 1 Peter was written during Peter's lifetime. Schreiner (2003:35), who, after weighing all the arguments, concludes that there were no decisive grounds for rejecting Petrine authorship of 1 Peter. The arguments for and against Petrine authorship - regarding (1) linguistics, style, vocabulary; (2) historical context; and (3) thought world of 1 Peter - are summarised in virtually all commentaries. Skaggs suggests that the suffering mentioned in 1 Peter possibly refers to people who fled from Nero's persecution, having lost relatives and/or friends (Skaggs 2004:7). ${ }^{2} 2$ Peter has the tone of a testament and may have been written shortly after his death. Many commentators date Jude before Peter.

The similarities between Jude and 2 Peter are particularly striking. Current consensus is that 2 Peter made use of Jude, ${ }^{3}$ but hardly anybody adequately explains the differences between the two. Possibly both letters used an Aramaic or Hebrew (oral or written) Vorlage of florilegia, an anthology of infidelity, apostasy and ảoéßeı $\alpha$. Snyder (1986:22) suggests the existence of a common source on which both epistles drew, either oral or written, designed to meet the needs of local communities which were facing various types of heresies and false teachers. A similar suggestion was made earlier by C Spicq. According to Spicq (1966:197), "nos deux auteurs s'inspirent, indépendamment l'un de l'autre, d'un document original, de Testimonia antihérétiques"; see also Schreiner (2003:418). The authors of Jude and Peter translated and edited this report, in which process both occasionally lapsed

\footnotetext{
${ }^{2}$ Schelkle (1980:11-15); Achtemeier (1996:1-9); Skaggs (2004:3-7).

${ }^{3}$ Paulsen (1992: 97-100); Harrington (2003:183 and 236); Callan (2004:42-64).
} 


\section{Pseudepigraphy and the Petrine school}

into Semiticisms. Those who assign Jude priority will have to explain why 2

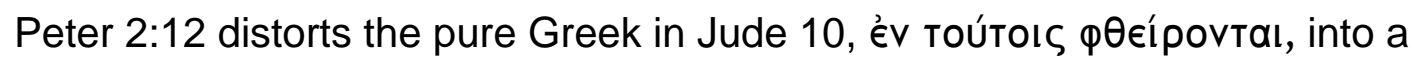

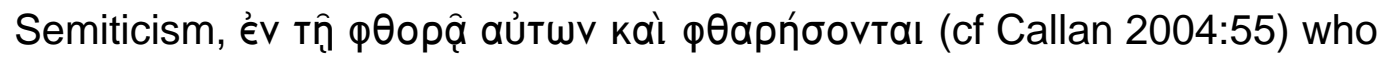
ignores the Semiticisms which he calls examples of paronomasia).

A Vorlage (in the form of a florilegium) would explain the thematic resemblances as well as the differences in vocabulary and terminology, such as the Semiticisms. Members of the same community could have used the same sources (florilegia) in different ways. The similarities display patterns of religion (Sanders), but the differences show that the authors, while using the same sources, were not copying each other.

\section{HYPOTHESIS OF A PETRINE SCHOOL}

Ethelbert Stauffer was one of the first exegetes to speak of a Petrine circle (Petruskreis). According to him Mark's gospel, the archetypal form (Urgestalt) of the passion narrative, Peter's discourses in Acts 1-12 and his first letter all derive from this Petrine circle in Rome (Stauffer 1948:17-19). This notion resurfaced in the 1970s in the work of Ernest Best (1971:59-63), who suggests that "the origin of 1 Peter lies in a school of disciples, the Petrine school."

These somewhat random references were first taken up seriously by John Elliott, who likewise assumed the existence of a Petrine school or group: "1 Peter is not only a testament to the Petrine legacy but also an expression of the theology of the Roman church of which Peter was a leading figure."4 Marion Soards (1988:3827-3849) expanded the Petrine output from 1 Peter to 2 Peter and Jude. Richard Bauckham (1983:161) confines the notion of a Petrine school to a Petrine circle in the loose sense of a group of working associates, including a good deal of theological diversity. This hypothesis is gaining increasing support, ${ }^{5}$ but also has its critics. ${ }^{6}$ David Horrell (2002:32) considers the letters too different to surmise a common underlying source or school. This is the only argument that Horrell adduces; for the rest he invokes mainly the (old) hypothesis of a Pauline and general early Christian influence on the various authors of the letters of Peter and Jude.

The hypothesis maintains that 1 and 2 Peter and Jude are products of a Petrine tradition, the "Petrine school", a group of authors comparable to the Johannine school that produced John's gospel and letters and the book of

\footnotetext{
${ }^{4}$ Elliott (2000:130); Elliott (1981); Elliott (1980:250-267).

${ }^{5}$ Bauckham (1983:161); Achtemeier (1996:42); Michaels (1988:Ixvi); Smith (1985:153, 208f); Knoch (1991:105-126).

${ }^{6}$ Horrell (2002:29-60); Schreiner (2003:25) Harrington (2003:253)
} 
Revelation. The next step would be to place James's letter in this framework. One of the common denominators between 1 and 2 Peter and Jude - to be explained below - is the use of wisdom literature; for the influence of wisdom literature on James, see Bauckham (1999).

Elliott (1980:253) believes that Peter, like Paul and others, operated in groups or teams. At all events, the Petrine group included "a Silvanus, a Mark and a Christian 'sister' (1 Pt 5:12-13)." If, like Bauckham, we take "group" to be a loose circle, one could assume that it included the historical figure of Jude. Here one thinks of the Jude in Acts 15:22 and 27. Silvanus (Silas) and

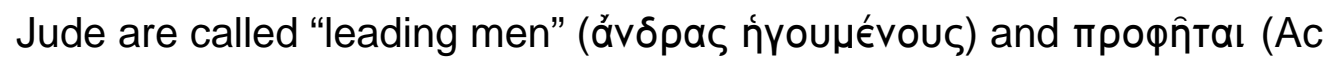

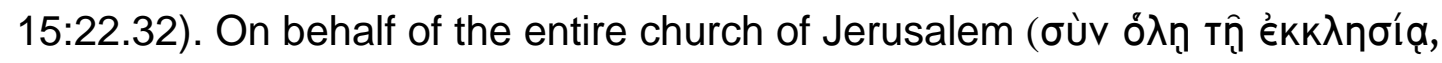
Ac 15:22) they deliver a letter to the church in Antioch. What arguments are there against identifying this Jude as the brother of James or of the Lord (hence the one to whom the pseudepigraphic title of Jude 1 refers)? The main objection appears to be that this identification would have been explicitly mentioned in Acts (Grundmann 1974:13f). Besides, it is argued, Jude is called "Barsabbas" (Skaggs 2004:148f). The arguments are not convincing. Firstly, James, too, is not called "the Lord's brother" anywhere in Acts (cf Ac 12:17; $15: 13 ; 21: 18$ ), yet nobody doubts it in view of his position and the relation to GI 1:19. Hence the same could apply to Jude, both a prophet and a leader. Secondly, Barsabbas is not a "surname" but simply means "son of the Sabbath"; or even, if one reads "Barsabas", "son of an old man". That is quite appropriate for Jesus' youngest brother (see Mt 13:15).

According to Elliott, the theological views of figures like Silvanus and Mark only become socially relevant if they worked in a group. Soards (1988:3828) presents four arguments for the view that 1 Peter, 2 Peter and Jude are best seen collectively and in association with this community. I want to endorse and extend them as follows:

- the literary similarities and differences between the documents are best explained by assuming several authors from the same community; in particular it explains the interest in the same (sometimes specified) apocryphal texts, the same biblical paradigms such as the Noah tradition, and the preference for the book of Proverbs;

- there are theological similarities, such as an eschatologically determined ethics, the salvific role of Christ, the notion of the elect and their divine (or holy) nature; 
- the three texts all have a liturgical basis - in 1 Peter baptism, and in 2 Peter and Jude the homily;

- $\quad$ by using specific Old Testament passages and pseudepigraphic sources the three texts display a trend of maintaining and handing down a written tradition;

- the need to maintain a common scriptural and exegetic tradition is the main cohesive factor in the three letters. The manner in which they defend this concern suggests a common origin.

\section{PATTERNS OF RELIGION (I): TRADITION AND SPIRIT IN 1 AND 2 PETER AND JUDE}

The concern to ensure the continuity of the tradition is the central theme of all three letters. It is most evident in 2 Peter and Jude, but is no less focal in 1 Peter. The aim of 1 Peter, as revealed in the conclusion to the letter, is to declare the true grace of God, émı Өєoû (1 Pt 5:12). Tradition plays a major role in this because, so the authors tell their readers, the prophets already prophesied the grace that was to be

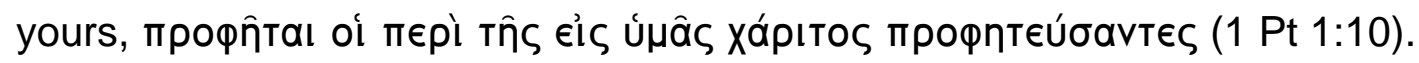
The line of this tradition runs via the prophets to those who preached the good

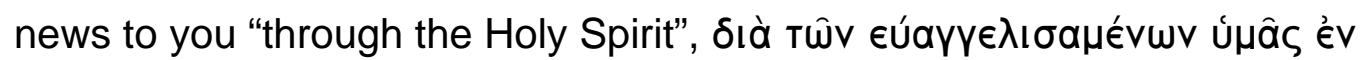

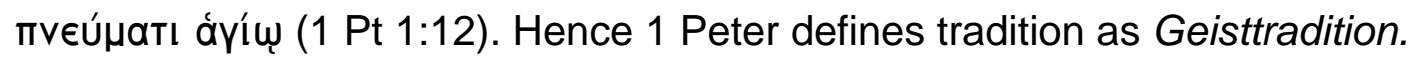

This relates directly to the concerns and aims of 2 Peter and Jude. In several places they emphasise their concern to "remind" their readers of something to which they should cling. To this end they use the verbs

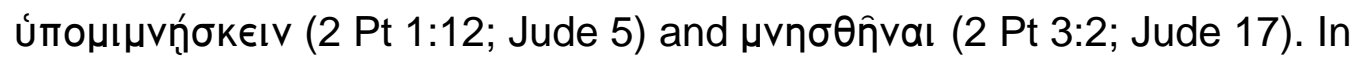
addition 2 Peter uses the noun úmó $\mu v \eta \sigma ı$ ( 2 Pt 1:13; 3:1). Reminding and reminder function as a pattern of religion. Another link between 1 Peter and 2 Peter is the notion of truth. Truth is something that comes from the past, from tradition. It is not something one can tamper with in the present or can handle as one pleases. One has to be reminded of it, although one already knows (єiठótas) it and lives in it - cf the connection between reminding and truth in 2

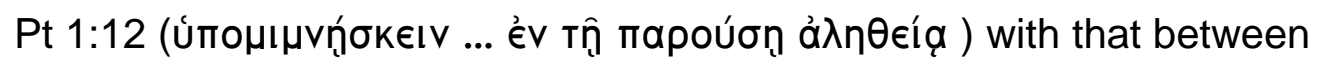

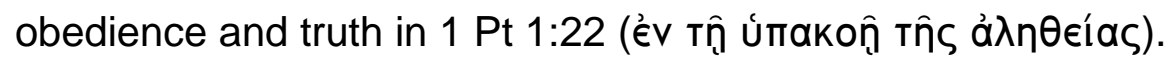

All three documents emphasise the link with the past. Jude asks his readers to contend for the faith "which was once for all delivered to the saints,

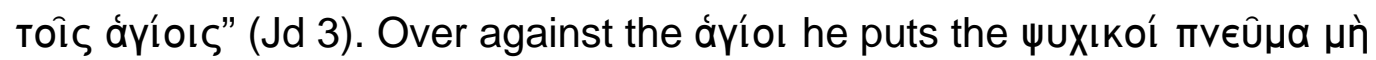
éхоvтєৎ, "worldly people, devoid of the Spirit" (Jd 19). 2 Peter 1:17-21 points 
out the authority of the prophets, who predicted the Son's glorification. The "we" in 2 Peter 1:19 is the apostolic "we": we have gained even greater respect for the prophets' prophecies because we witnessed their fulfilment, that is, the glorification of the Son. Therefore, the argument continues in 2 Peter 2:19ff (not logically, though it does reveal the authors' concern), you must stick to (пробе́хоvтєৎ) the prophecies and make a distinction between

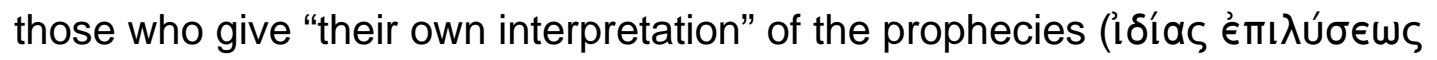

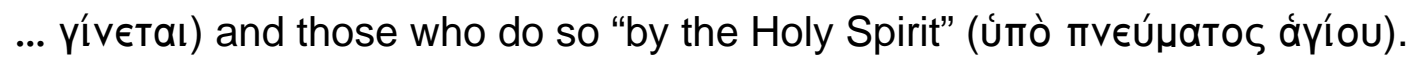
Thus 2 Peter likewise has a Geisttradition (cf 2 Pt 1:21 with 1 Pt 1:12).

The ability to discern who is speaking in the Spirit (Geisttradition) is a pattern of religion in Sanders's sense. It determines who are adherents of the religion and who are not. At the same time the authors are claiming competence to remind people of things and to interpret them. Anyone who does not have the Spirit and cannot invoke tradition is "ignorant and unstable":

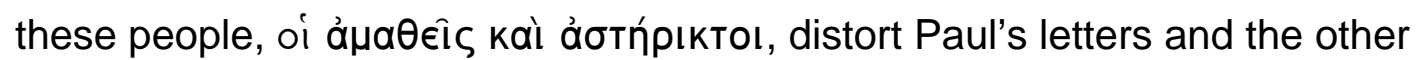
scriptures (2 Pt 3:15f). here in 2 Peter 3:15 beginns, according to Schelkle (1980:237), "die römisch-katholische Kirche im NT, deren Säulen und Lehrer Petrus und Paulus als römische Apostelfürsten sind."

Tradition and exegesis, the readers of 1 and 2 Peter and Jude are left to conclude, are safe in the hands of those who have the Spirit, such as the authors of these letters: Simon Peter and Jude, the brother of James.

\section{PATTERNS OF RELIGION (II): TRUTH AND RIGHTEOUSNOUSS}

A special link between the three letters is the strong relation between faith (doctrine, fides quae creditur) and conduct (ethics, fides qua creditur). Analogous to the Hebrew twin concepts מסר (cf Ps 40:12; 57:4), the notions truth and righteousness are paired.

In 1 Peter ethics and faith are very much complementary. Household codes or Haustafel are balanced against tradition and faith. This is already

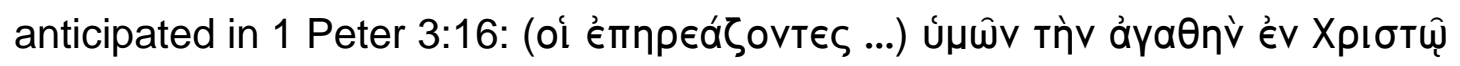
åvaбтрофńvi: (a) good behaviour and (b) being in Christ go together. Peter uses the expression "in Christ" three times $(3: 16 ; 5: 10 ; 5: 14)$ and, except for the Pauline letters, it occurs nowhere else in the New Testament. Paul gives it a mystical connotation of mutual indwelling (Christ in me, I in Christ; GI 2:19ff). To Peter this immanence implies a responsibility for Christians. The fact that they live "in Christ" and "the hope that is in [them]" (1 Pt 3:15) are the main arguments for the petitio (household codes) in this letter. 
This balance between behaviour and being in Christ reaches its acme in 4:15-19, the crux of the recapitulation of 1 Peter. The judgment, тò kpí $\mu$ a (1 Pt 4:17), is measured, we infer from this passage, according to two criteria:

- an ethical criterion: 1 Peter 4:15f requires - along with the many other injunctions and lists of virtues (and vices) in 1 Peter 2:1-3:17 - an exemplary life, "good behaviour in Christ" (1 Pt 3:16);

- a criterion of faith and trust: those who trust in God, in the name of Jesus Christ, can be sure of grace; in 1 Peter 4:17 this criterion is

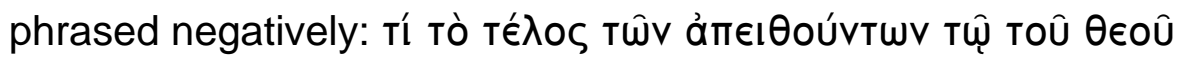

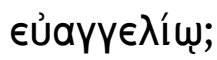

The author of the letter concedes that this is a really tough criterion: "... [even] the righteous man (ó díkaış) is scarcely saved" (1 Pt 4:18). "And where," he continues dolefully with a quotation from Proverbs 11:31, "will the impious (o

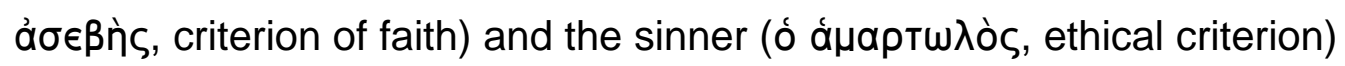
appear?"

The two criteria are summed up in the last verse in this passage: people should do right, åjaӨoпоía, and entrust their souls to a faithful Creator,

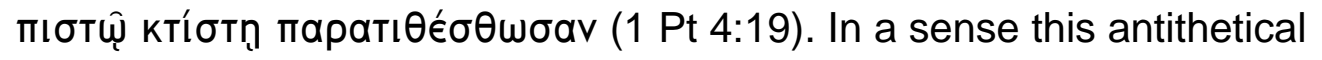
argument epitomises the letter:

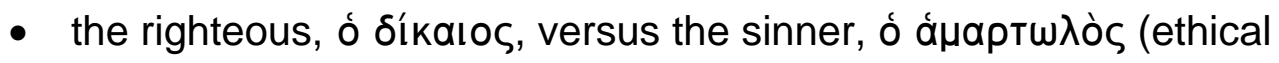
criterion);

- the Christian, ó Xpıotıavós, versus the ungodly, ó ảo€ßǹৎ (criterion of faith).

In 1 Peter the truth of faith (fides quae) is manifested only in the ethics of love and forbearance (fides qua). It is no different in 2 Peter and Jude.

Remarkably, Peter's second letter does not condemn false teachers primarily on account of their Christological or theological views but on account of their morality: their licentiousness and greed (2 Pt 2:2f). Peter's accent on morality rather than doctrine means that one should not be too quick to identify the false teachers with gnostics. Libertines, antinomians, possibly even epicureans are more likely (Neyrey 1993:122-128). Neyrey (1993:127f) points out that the Hebrew word for "scoffer" (2 Pt 3:3; Jude 18), Apikoros, appears to be related to the Greek "Epicurian." 
Licentiousness distracts teachers from the way of truth, í ódò Tn̂s

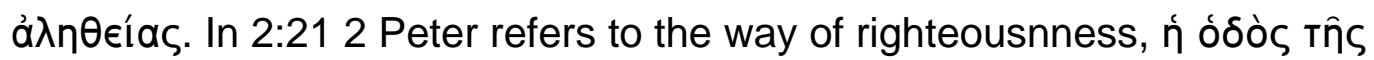

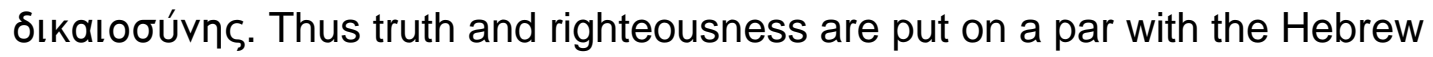
terms, חסר חס (cf Ps 40:12; 57:4). Hence truth is not so much a dogma to be accepted cognitively, but an attitude to life that affects behaviour. In 2 Peter, therefore, odious conduct is tantamount to heresy. Heresy is bad behaviour, and vice versa. That is why greed is equated with "false words" (2 Pt 2:3).

The threefold parallellism between doctrine and morality makes it clear that there is little or no difference between fides qua and fides quae:

- heresies are associated with death and destruction (the double åmú $\lambda \in \operatorname{l} \alpha$ in 2 Pt 2:1);

- licentiousness is associated with falsehood (2 Pt 2:2);

- greed is associated with false words (2 Pt 2:3).

This is the same balance between morality and doctrine (household codes and faith) that we observe in 1 Peter.

We find the same relationship in Jude. According to Jude 3 the letter is an exhortation to contend for the one faith delivered once for all to the saints,

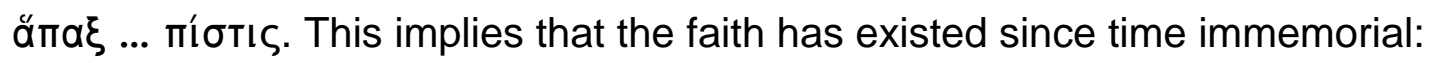
it existed even before the saints, was delivered to them, and now "those who

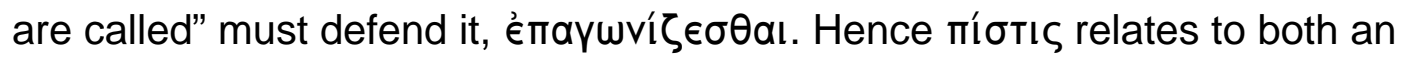
activity, the believer's "believing" (fides quae), and a doctrine, the "faith" that existed from time immemorial (fides qua).

Doctrine concerns two issues, which encapsulate the substance of Jude's theology: faith in the only God and the salvation he brings through Jesus Christ (Jd 4:25). This faith, this "theology" must be defended against "infiltrators" (Schelkle 1980:151ff). Schelkle sees "faith" in Jude as doctrine or content (fides quae). By contrast, M de Jonge (1966:19f) maintains that Jude seeks to distinguish between genuine and false prophecy, analogous to Matthews's behavioural criterion that a tree is known by its fruits (Mt 7:15-20); the pneumatic infiltrators invoke the wrong kind of enthusiasm but come a cropper because they do not live in the way the Lord requires (fides qua). Both aspects - the substance of faith (fides quae) and the concomitant attitude (fides qua) - are to be found in Jude's letter. He insists on good

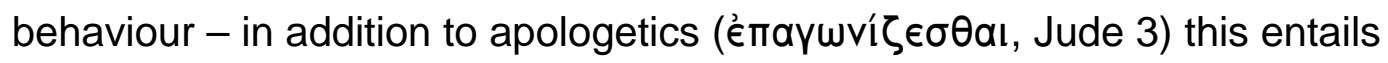


presentation without blemish (ả $\mu \omega ́ \mu o u \varsigma$, Jude 24) - and correct religious belief: accepting that Jesus Christ is "our only Master and Lord" (Jude 4). Theologically Jude 4 is an interesting verse, because it opens up various christological possibilities. Some old manuscripts append Ө€ós to "Master and Lord". But even without this supreme Christological title Jude assigns Jesus names and functions - judge, the one who gives é $\lambda \in O \varsigma$ ( $\mathrm{Jd} 21)$, lord and master - which the Old Testament associates with God.

We conclude that, whereas 2 Peter (1:19-21) puts the accent on tradition and interpretation, Jude puts it on tradition and apologetics (Jude 3). Together with adherence to tradition, the identification of morality and doctrine

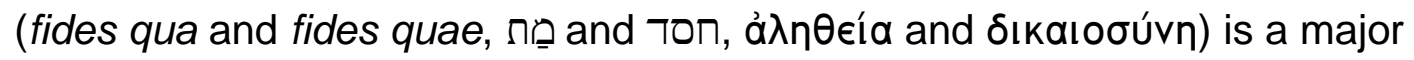
link between the three letters.

\section{PATTERNS OF RELIGION (III): DISOBEDIENCE OF THE UNGODLY}

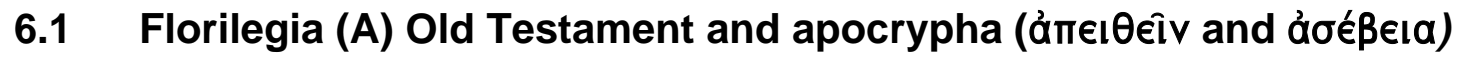

The letters of Peter and Jude contrast those who have the Spirit with apostates and unbelievers. In this context 1 Peter prefers the expressions

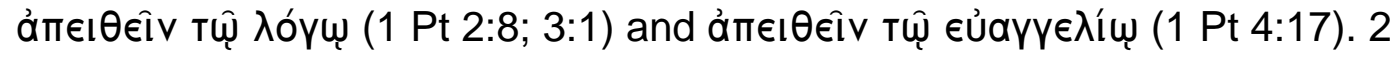

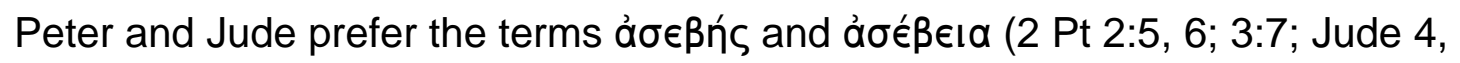
15, 18; also see 1 Pt 4:18).

The most striking parallel is the use of the Noah story via 1 Enoch. Jude makes no direct reference to the story of the flood but links up with Enoch's narrative about the angels who leave "their proper dwelling (тò " o oıv oikntńpiov)" (cf Jude 6 with 1 En 12:4; 15:3), for which they are kept in captivity till the day of judgment (cf Jude 6 with 1 En 10:6; 22:11f). Anyone who compares 2 Peter 2:4 with Jude 6 - and believes that the one was copying the other - must be surprised by the lack of similarities. If there is any literary dependence at all, it is only through the agency of 1 Enoch. 2 Peter 2:4 collates parts of 1 Enoch 10:4f, 10:11-14 and 91:15. Also 1 Peter 3:19 appears to refer to 1 Enoch (especially 1 En 9:10, 10:11-15). However, the verbal disparities between 1 and 2 Peter and Jude are too great to permit an assumption of dependence between them. It seems more likely that each author used passages from Enoch, making his own Greek translation. "The thesis that part of 1 Enoch ... was composed partially in Aramaic and partially in Hebrew has to be considered probable" (Isaac 1983:6).

That would mean that the Petrine school used (parts of) the book of Enoch in an Aramaic or Hebrew version. In view of their concern, these excerpts would have been mainly instances of infidelity and apostasy. Such 
excerpts, together with other Old Testament texts, might have formed a florilegium of texts recording disobedience. Other candidates for this florilegium would be examples of infidelity on the part of Cain, Balaam and Korah, Israel in the wilderness, and the cities of Sodom and Gomorrah; possibly also the texts from psalms and the prophetic books used in 1 Peter. ${ }^{7}$ These (partly oral) sources are used apologetically by the Petrine school to counter opponents in its own ranks. The sources are reflected in the letters in various ways, with differences in verbiage, individual emphases and with or without Semiticisms.

Jude:

1. Israel in the wilderness (5)

2. fallen angels (6)

3.

4. Sodom and Gomorrah (7)

5. Cain (11)

6. Balaam (11)

7. Korah (11)
2 Peter:

sinning angels (2:4)

the flood (2:5)

Sodom and Gomorrah (2:6)

Balaam (2:15)
1 Peter:

(once no people, now God's people; 2:10) spirits in prison (3:19) the flood (3:20f)

(evildoers; 3:12)

Possibly the paradigms in the florilegium contained instances of faithfulness as well as examples of infidelity. Lot in 2 Peter 2:7f, Sarah in 1 Peter 3:6 and the archangel Michael in Jude 9 could be representatives of faithfulness. The prototype of the righteous human being is, of course, Christ, of whom 1 Peter 3:18 says that he was put to death as "the righteous for the unrighteous

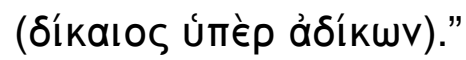

\subsection{Florilegia (B) The chokmatic tradition}

Another florilegium that the Petrine school might have used could be texts from chokmatic literature, like Proverbs, Wisdom of Solomon and the Wisdom of the Son of Sirach. A dominant theme in chokmatic literature is eschewing the delusions of the ungodly, as spelled out at the outset (Prv 1:10; Sap 1:4; Sir 1:21). ${ }^{8}$ In 1 and 2 Peter and Jude, too, the warning against the ungodly

\footnotetext{
${ }^{7}$ See especially the concentration of quotations in 1 Pt 2:4-10, e g Ps 117:22 (LXX) in verses 4 and 7 , Is $28: 16 ; 8: 14 ; 43: 20-21 ; 42: 12$ in verses $4,6,8$ and 9 , Ml 3:17 in verse 9 and $\mathrm{Hs}$ 1:6.9; $2: 25$ in verse 10 . See also Ps 34:13-17 in 1 Pt 3:10-12 as an example of a text contrasting unbelief and righteousness.

${ }^{8}$ Collins (1997:42-96); Sterling (2005:131-154).
} 
and the disobedient is a cohesive theme. The following table shows that chokmatic texts feature explicitly in Peter's and Jude's letters:

\begin{tabular}{|c|c|c|c|}
\hline $\begin{array}{l}\text { Petrine } \\
\text { school }\end{array}$ & $\begin{array}{l}\text { chokmatic } \\
\text { text }\end{array}$ & content & allusion/quotation \\
\hline 1 Pt 1:7 & Prv 17:3 & (testing of gold) & allusion of words \\
\hline $1 \mathrm{Pt} 1: 13$ & Prv 31:17 & (gird up the loins/your mind) & allusion of words \\
\hline $1 \mathrm{Pt} 2: 17$ & Prv 24:21 & (fear God and do not disobey the king) & allusion of ideas \\
\hline 1 Pt 3:6 & Prv 3:25 & (оủ фоßnӨńбn птónбıv) & $\begin{array}{l}\text { allusion, nearly } \\
\text { quotation (from LXX) }\end{array}$ \\
\hline 1 Pt 4:8 & Prv 10:12 & (love covers a multitude of sins) & $\begin{array}{l}\text { quotation (translation } \\
\text { from the Hebrew) }\end{array}$ \\
\hline 1 Pet 4:18 & Prv 11:31 & 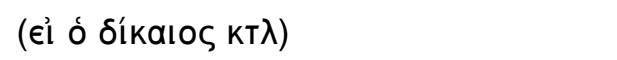 & quotation (from LXX) \\
\hline $1 \mathrm{Pt} 5: 5$ & Prv 3:34 & 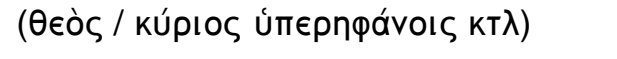 & quotation (from LXX) \\
\hline $1 \mathrm{Pt} 2: 25$ & Sap 1:6 & 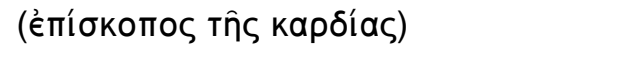 & allusion of words \\
\hline 1 Pt 5:6 & Sap 12:13 & 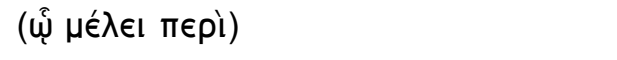 & allusion of words \\
\hline $1 \mathrm{Pt} 1: 3$ & Sir 16:12 & 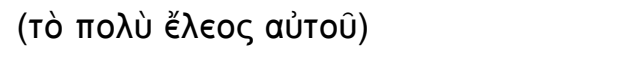 & allusion/quotation \\
\hline Jude 12 & Prv 25:14 & (clouds, wind, but no rain) & allusion of words \\
\hline Jude 5 & Sap 10:15ff & (Lady Wisdom, Lord Jesus Christ) & allusion of ideas \\
\hline Jude 7 & Sap 10:7f & 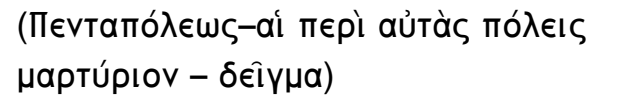 & allusion of ideas \\
\hline Jude 10 & Sap 11:15 & (irrational beasts) & allusion of words \\
\hline Jude 11 & Sap 10 & (themes from the Pentateuch) & allusion of ideas \\
\hline Jude 13 & Sap 14:1 & (raging waves) & allusion of words \\
\hline Jude 25 & Sir 1:1 & 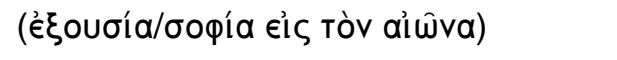 & allusion of words \\
\hline 2 Pt 2:21 & Prv 21:16 & 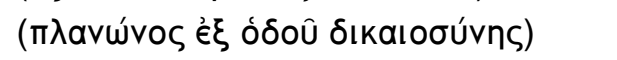 & allusion of ideas \\
\hline 2 Pt 2:22 & Prv 26:11 & (the dog returning to his own vomit) & $\begin{array}{l}\text { quotation (translation } \\
\text { from Hebrew) }\end{array}$ \\
\hline 2 Pt 2:2 & Sap 5:6 & 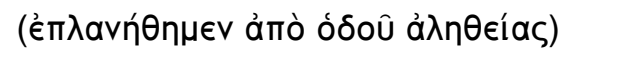 & allusion of ideas \\
\hline 2 Pt 2: 7 & Sap 10:6 & (righteous versus ungodly people) & allusion of ideas \\
\hline 2 Pt 2:12 & Sap 11:15 & (irrational beasts) & allusion of words \\
\hline 2 Pt 3:9 & Sir 35:19 & 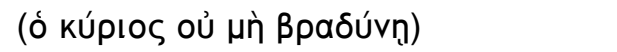 & allusion/quotation \\
\hline 2 Pt 3:18 & Sir 18:10 & 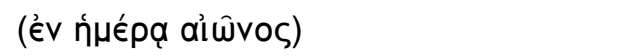 & allusion of words \\
\hline
\end{tabular}

The use of Proverbs in 1 Peter shows that the authors sometimes quote from the Septuagint (1 Pt 4:18, 5:5) and sometimes translate the Hebrew text (1 Pt 4:8); see however Schelkle (1980:118). Probably the scroll was available in both a Greek and a Hebrew version. It is by no means a foregone conclusion that 1 Peter 3:6 is quoting Proverbs 3:35. Some scholars maintain that Proverbs 3 played a major role in the early church (Selwyn 1946:408-09 [Table VIII A]; 413 and 435). The significance of this book in the Petrine letters confirms this view. 
On the whole the Petrine school's interest in chokmatic literature can be explained as fear of apostasy and the appearance of false teachers and infiltrators. Jude 7 and 11 (Sodom and Gomorrah, Cain, Balaam and Korah) could well pass as a synopsis of the Wisdom of Solomon 10 which, without mentioning any names, alludes to key events in the Pentateuch. 2 Peter 2:7ff cites other events from the Wisdom of Solomon 10, including the theme of the flood and Lot's vicissitudes. As in the case of the book of Enoch, this indicates that various writers in the Petrine school may have used the same sources, but in their own ways.

A remarkable intertextual relation between Jude and the Wisdom of Solomon is the way stories from the Pentateuch are recounted. Shannon Burkes shows how Lady Wisdom is assigned a leading role in the historical review of Israel's past in the Wisdom of Solomon 10:1-21 (Burkes 2003:167). She takes God's place by delivering the Israelites from Egypt (Sap 10:15) and precedes them at night as a pillar of flame (Sap 10:17). In Jude $4 f$ we find the replacement of God by Lady Wisdom replicated by God's replacement by the Lord Jesus Christ: "Ungodly persons ... deny our only Master and Lord (Tòv

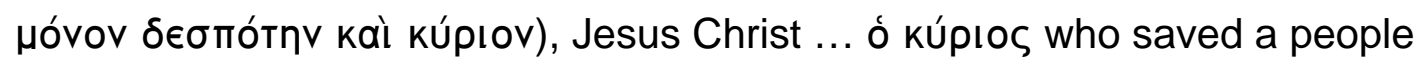
out of the land of Egypt, afterward destroyed those who did not believe."

According to some commentaries, the redeeming kúpıos in Jude 5 refers to God, not Christ. There is no reason for this assumption if Jude's Christology was influenced by the Wisdom of Solomon 10. Besides, many early manuscripts like the Codex Alexandrinus and the Codex Vaticanus have

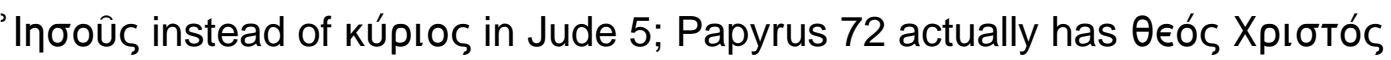
(Schelkle 1980:144).

\section{PATTERNS OF RELIGION (IV): ETHICS, SANCTIFICATION, AND ESCHATOLOGY}

Karl Hermann Schelkle (1980:241) hails 2 Peter "als erster Versuch einer Apologie der christlichen Eschatologie." If one takes "apologia" to mean "trying to persuade opponents in a debate", that is not altogether correct. The addressees of the letter are not critics and opponents - the "scoffers

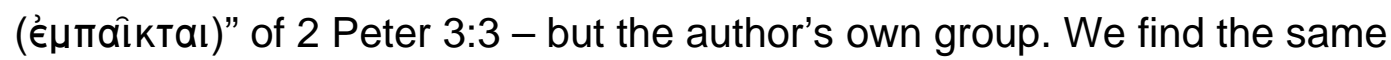

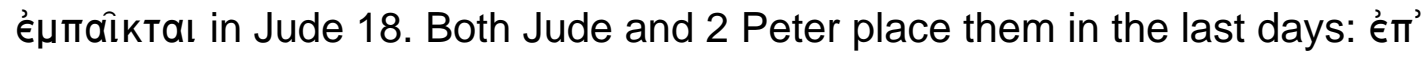

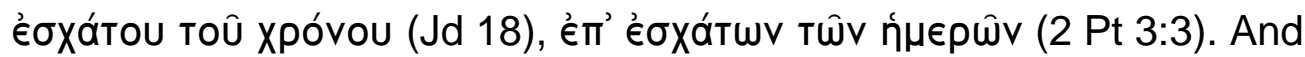
although Jude does not mention the parousia, it is clear from Jude $17 \mathrm{f}$ that Christian eschatology is an object of derision. If this is an apologia, then it is directed to the inner circle, not the outside world. The actions of the érпаikтаı is a sign that the end-time was at hand. How exactly it would come about 


\section{Pseudepigraphy and the Petrine school}

(descriptive) is less relevant to 2 Peter than that it was imminent (constative, almost performative). "Wenn aber endlich die neue Schöpfung mit dem ganz unmythologischen Satz beschrieben wird: Es wird dort die Gerechtigkeit wohnen $(3,13)$, so wird es fraglich, ob dem Brief an der Wörtlichkeit der vorhergehenden apokalyptischen Schilderung liegt" (Schelkle 1980:241).

Both 2 Peter and Jude connect eschatology with a code of conduct: "Since all these things are thus to be dissolved, what sort of persons ought

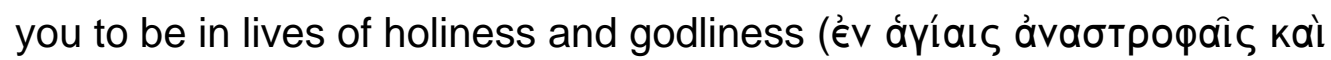

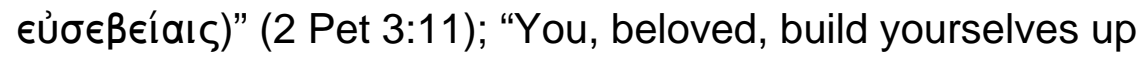

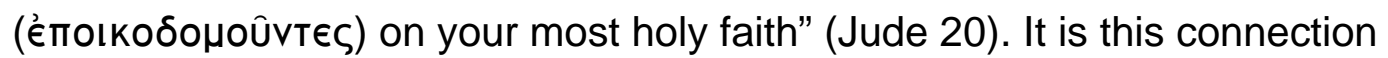
between ethics and eschatology that links 2 Peter and Jude with 1 Peter in a pattern of religion.

In 1 Peter, too, the parousia and the end-time are closely connected with behavioural rules. First he associates the salvation to be revealed to the faithful at the end of time with the revelation of Jesus Christ (1 Pt 1:5, 7). But then he proceeds to connect this eschatology with an injunction to behave in a particular way: "Therefore gird up your minds, be sober, set your hope fully upon the grace that is coming to you at the revelation of Jesus Christ" ( $1 \mathrm{Pt}$ 1:13; also see 2:12, where the "day of visitation" has an ethical purport). This injunction culminates in a summons to sanctification: "Be holy yourselves in all

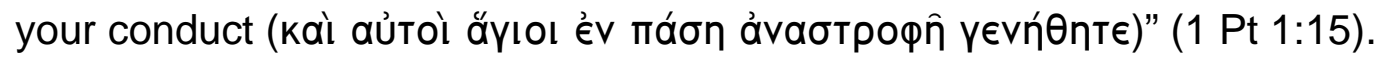
This is the same as the call for sanctification in 2 Peter 3:11 and Jude 20.

The Petrine school wants its congregation to see itself as a community of saints at the end of time. Accordingly, 1 Peter addresses its readers as a chosen race and an éقvos ăyıov (1 Pt 2:9). The same idea underlies 2 Peter $1: 4$, which regards the congregation as partakers of the divine nature:

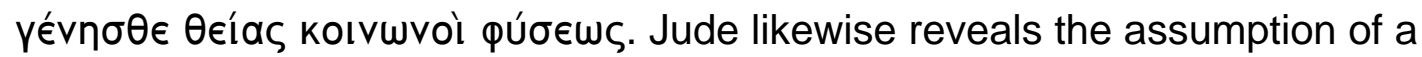
holy community, in that he considers those to whom the faith has been handed down as saints: ó áyíoı (Jude 3).

The letters of Peter and Jude seek to give their readers an ethical awareness of a community of saints at the end of time. The combination of ethics, sanctification and eschatology constitutes a major link between the three documents.

\section{CONCLUSIONS}

The hypothesis of a Petrine school assumes three groups: (a) the actual authors and the "implied authors" or "ghostwriters", like Peter and Jude, the brother of James, (b) the community from which they are writing (probably 
Rome $^{9}$ ) that consented to the use of the pseudepigraphic heading, and (c) the communities to which they are writing. This results in the somewhat odd impression that the authors are not primarily addressing distant churches, but that their first concern is for their own community, from whom they had to obtain permission to dispatch their letters under that title and with those contents. This consent, the amendments and discussion of the contents in congregational meetings make the letters communal products.

A major implication of this approach is that the documents can also be regarded as a mirror of the situation of the senders. After all, if the 'first readers' were the members of their own congregation, then their situation would play a special role. The ordeal referred to in 1 Peter 4:12, the false teachers in 2 Peter 2:1 and the infiltrators in Jude 4 could correspond with problems faced by the church in Rome in the sixties and seventies of the first century. Because these were problems that one could imagine occurring in all young churches - the behaviour of $\psi \epsilon \cup \delta \alpha$ по́бтоло in the church of Corinth in the fifties is an early example (2 Cor $11: 13$ ) - the letters were copied and sent to other churches.

The Petrine school developed ideas and conceptions that can be described as patterns of religion. These patterns - characteristic of Peter's and Jude's letters and establishing an indissoluble link between them - are the following:

1. the notion that the Spirit was active in tradition; a major implication of this notion is that the new communities should turn their backs on

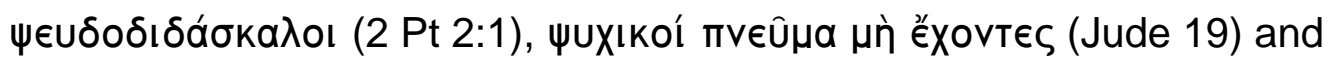

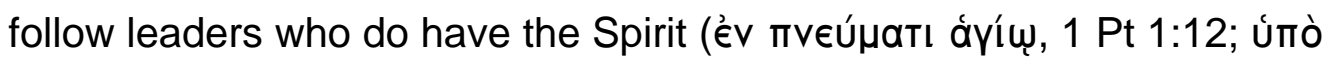
пvєúpatos áyíou, 2 Pt 1:21);

2. the notion that truth and righteousness go together (fides quae and fides qua);

3. the notion that there is a direct relation between ethics, sanctification and eschatology.

\footnotetext{
${ }^{9}$ This is what the probably metaphorical "Babylon" in 1 Peter 5:13 indicates. Commenting on 2 Peter, Bauckham (1983:159) says that the letter can plausibly be set within the context of the Roman church's pastoral concerns for churches elsewhere during the late first century. Many authors place Jude against a Palestinian background; however, the sometimes perfect Greek, the Hellenistic influences and the prominent role of apocryphal texts could suggest a non-Palestinian background. Gerdmar's (2001:255-277) reversed heuristics leads him to find all sorts of Hellenistic influences in Jude, but he nonetheless adheres to a Palestinian background (Gerdmar 2001:311).
} 


\section{Pseudepigraphy and the Petrine school}

In addition there are various florilegia which the various authors used in their respective ways. That explains not just the similarities between the letters, but more especially the differences like the Semiticisms, the dissimilar use of words and the different examples - the authors made their own translations and selection from the available documents. One florilegium could have comprised texts from the Old Testament and the apocrypha (e g Enoch and Assumptio Mosis) that contained instances of infidelity and ungodliness (Tromp 2003:323-340). Tromp (2003:325) thinks that the words from Jude 9

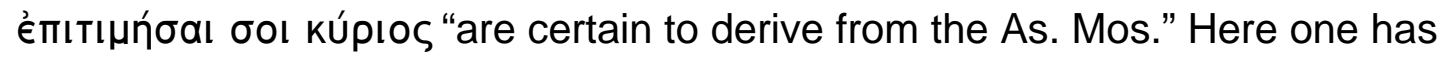
to beware of a circular argumentation: from Jude 9 (and other texts) one reconstructs the lost ending of the Assumptio Mosis from which Jude 9 is a quotation. A second florilegium could have comprised texts from the chokmatic tradition, like Proverbs, Wisdom of Solomon and the Wisdom of the Son of Sirach. The two florilegia together reveal a single, clear pattern of religion:

4. the idea that ungodliness and infidelity are always lurking and should be feared from within rather than from without.

Distancing themselves from these ungodly people and aware of the constant danger of apostasy, the authors of the letters of Peter and Jude strengthen their congregants' consciousness that they are a community of saints living at the end of time. The exhortation to the congregation to turn their backs on

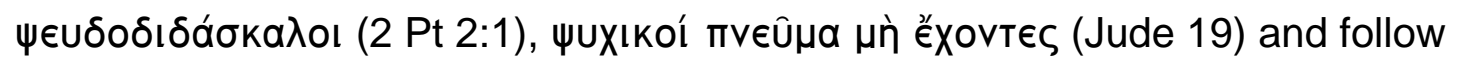
persons who do have the Spirit could be seen as a catholic Roman concern. It represents a stage preceding the early Catholicism (Frühkatholizismus) of Christian documents from the post-apostolic period, which anticipated the ideas of the 3rd and 4th century fathers. Early Catholicism has certain features in common with the patterns of religion in 1 and 2 Peter and Jude such as the notion of inspiration by the Holy Spirit and a centralised doctrinal authority - but it also has attributes that rarely if ever feature in these letters, such as the idea of a canon, the doctrine of the sacraments, the perception of the priesthood as a function of salvation, and especially the abandonment of eschatology as the focus of faith (Fornberg 1977:3f). Schelkle (1963:225-232) and Käsemann (1967:214-223) refer, specifically in regard to 2 Peter and Jude, to a "spätapostolisches Zeugnis des Frühkatholizismus." One can argue about the dating of the letters, ${ }^{10}$ but because 1 and 2 Peter and Jude do not

\footnotetext{
${ }^{10}$ There appears to be consensus on a dating of 2 Peter and Jude at the end of the 1 st century or the early 2 nd century, but judging by repeated attempts at an earlier dating no argument appears to be conclusive; for recent early datings (Van Houwelingen 1993; Skaggs 2004; Brosend 2004).
} 
display all the features of early Catholicism - at any rate not cardinal ones like the abandonment of eschatology as the focus of faith ${ }^{11}$ - they should be dated earlier than the post-apostolic documents. This is counter to Knoch's somewhat ambivalent position in his article "Gab es eine Petrusschule in Rom?". On the one hand Knoch (1991:125) considers the Petrine school in Rome to be the centre of the church: "Als Paulus dort ankommt, wahrscheinlich 60/61 n.Chr., ist die Gesamtgemeinde nach dem Vorbild Palästinas großkirchlich-petrinisch geprägt." On the other hand he thinks that Peter's letters are post-apostolic; the Petrine school "verstand sich ... als Anwalt der apostolischen Glaubensüberlieferung, der Einheit und des Lebens der Kirche im Kampf gegen Verfolgung und Irrlehre" (Knoch 1991:123 and 126).

Between AD 60 and 90 there were various centres that sought to influence the Christian churches by way of letters and other documents. The Petrine school in Rome stood alongside, not above other schools like the Johannine community in Ephesus and the deutero-Pauline schools in Antioch and elsewhere.

In the first century there was as yet no question of any effective centralisation of the faith and doctrinal authority, though there were attempts at both.

\section{Works consulted}

Achtemeier, J 1996. 1 Peter: A commentary on first Peter. Minneapolis, MN: Augsburg Fortress. (Hermeneia.)

Aland, K 1961. The problem of anonymity and pseudonymity in Christian literature of the first two centuries, The Journal of Theological Studies 12, 39-49.

Aland, K 1980. Noch einmal: Das Problem der Anonymität und Pseudonymität in der christlichen Literatur der ersten beiden Jahrhunderte, in Dassmann, v E \& Frank, K S (Hrsg), Pietas: Festschrift für Bernhard Kötting, 121-139, Münster (Westfalen): Aschendorff.

Balz, H R 1969. Anonymität und Pseudepigraphie im Urchristentum. Überlegungen zum literarischen und theologischen Problem der urchristlichen und gemeinantiken Pseudepigraphie. Zeitschrift für Theologie und Kirche, 66, 403-436.

Bauckham, R J 1983. 2 Peter, Jude. Waco, TX: Word Books. (Word Biblical Commentary 50.)

Bauckham, R J 1999. James: Wisdom of James, disciple of Jesus the sage. London: Routledge.

\footnotetext{
${ }^{11}$ Fornberg (1977:6) considers Frühkatholizismus an inappropriate term for describing 2 Peter. In his view the German controversy between Protestant and Catholic exegetes in the1960s and 1970s (respectively headed by Käsemann \& Schelkle) reflects "the confessional divisions of our time".
} 
Baum, A D 2001. Pseudepigraphie und literarische Fälschung im frühen Christentum: mit ausgewählten Quellentexten samt deutscher Übersetzung. Tübingen: Mohr Siebeck.

Best, E 1971. 1 Peter. London: Sheffield Academic Press. (New Century Bible.) Bigg, C [1901] 1987. The epistles of St Peter and St Jude. Edinburgh: T\&T Clark. Brosend, W J 2004. James and Jude. Cambridge: Cambridge University Press. (New Cambridge Bible Commentary.)

Brown, R E 1979. The community of the beloved disciple: The life, loves and hates of an individual church in New Testament times. Mahwah: Paulist Press.

Brox, N 1975. Falsche Verfasserangaben: Zur Erklärung der frühchristlichen Pseudepigraphie. Stuttgart: KBW Verlag.

Burkes, S 2003. God, self and death: The shape of religious transformation in the second temple period. Leiden: Brill. (Suppl to the Journal for the Study of Judaism 79.)

Callan, T 2004. Use of the letter of Jude by the second letter of Peter. Biblica 85, 4264.

Collins J J 1997. Jewish wisdom in the hellenistic age. Louisville, KY: Westminster John Knox.

De Jonge, M 1966. De nieuwtestamenticus als historicus en theoloog: Enige opmerkingen naar aanleiding van de brief van Judas. Leiden: Brill.

Donelson, L R 1986. Pseudepigraphy and ethical argument in the pastoral epistles. Tübingen: Mohr.

Elliott, J H 1980. Peter, Silvanus and Mark in I Peter and Acts: Sociologicalexegetical perspectives on a Petrine group in Rome, in Haubeck W \& Bachmann M (Hrsg), Wort in der Zeit: Neutestamentlichen Studien. Festgabe für Karl Heinrich Rengstorf zum 75. Geburtstag, 250-267. Leiden: Brill.

Elliott, J H [1981] 1990. A home for the homeless: A sociological exegesis of 1 Peter, its situation and strategy. Minneapolis, MN: Wipf \& Stock.

Elliott, J H 2000. 1 Peter. New York: Anchor Bible. (The Anchor Bible 37B.)

Fornberg, T 1977. An early church in a pluralistic society: A study of 2 Peter. Lund: LiberLäromedel/Gleerup.

Gerdmar, A 2001. Rethinking the Judaism-Hellenism dichotomy: A historiographical case study of second Peter and Jude. Stockholm: Almqvist \& Wiksell International.

Grundmann, W 1974. Der Brief des Judas und der zweite Brief des Petrus. Berlin: Evangelische Verlaganstalt. (Theologischer Handkommentar zum Neuen Testament XV.)

Harrington, D J 2003. Jude and 2 Peter, in Harrington, D J \& Senior, D (eds), 1 Peter, Jude and 2 Peter. Collegeville, MN: Michael Glazier Books. (Sacra Pagina Series 15.)

Harrison, P N 1921. The problem of the pastoral epistles. London: Oxford University Press.

Horrell, D G 2002. The product of a Petrine circle?: A reassessment of the origin and character of 1 Peter. Journal for the Study of the New Testament 86, 29-60.

Isaac, E 1983. 1 (Ethiopic Apocalyse of) Enoch: A new translation and introduction, in J H Charlesworth (ed), The Old Testament Pseudepigrapha, 5-89. New York: Anchor Bible. (Vol I, Apocalyptic Literature \& Testaments.) 
Käsemann, E 1967. Begründet der neutestamentliche Kanon die Einheit der Kirche?, in Exegetische Versuche und Besinnungen, I, 214-223. Göttingen: Vandenhoeck \& Ruprecht.

Knoch, O B 1991. Gab es eine Petrusschule in Rom? Überlegungen zu einer bedeutsamen Frage. Studien zum Neuen Testament und seiner Umwelt (A) 16, 105-126.

Metzger, B 1972. Literary forgeries and canonical pseudepigrapha. Journal of Biblical Literature 91, 3-24.

Michaels, J R 1988. 1 Peter. Waco, TX: Nelson. (Word Biblical Commentary 49.)

Mitton, C L 1951. The epistle to the Ephesians. Oxford: Blackwell.

Neyrey, J H 1993. 2 Peter, and Jude: A new translation with introduction and commentary. New York: Anchor Bible. (Anchor Bible 37C)

Paulsen H 1992. Der Zweite Petrusbrief und der Judasbrief. Göttingen: Vandenhoeck \& Ruprecht. (Kritisch-exegetischer Kommentar über das Neue Testament $\mathrm{XII} / 2$.

Sanders, E P 1977. Paul and Palestinian Judaism: A comparison of patterns of religion. Philadelphia, PA: Augsburg Fortress.

Schelkle, K H 1963. Spätapostolische Briefe als frühkatholisches Zeugnis, in J Blinzler et al (Hrsg), Neutestamentliche Aufsätze: Festschrift für Prof Josef Schmid zum 70. Geburtstag, 225-232. Regensburg: Verlag Friedrich Pustet.

Schelkle, K H 1980. Die Petrusbriefe: Der Judasbrief. Freiburg: Herder. (Herders Theologischer Kommentar zum Neuen Testament, Band XIII, 2.)

Schmidt, K H 2003: Mahnung und Erinnerung im Maskenspiel: Epistolographie, Rhetorik und Narrativik der pseudepigraphen Petrusbriefe. Freiburg: Herder.

Schreiner, T R 2003. 1, 2 Peter, Jude, Nashville, TN: Broadman \& Holman.

Selwyn, E G 1946. The first epistle of St Peter. London: St Martin's Press.

Skaggs, R 2004. 1 Peter, 2 Peter, Jude. London: Pilgrim Press. (The Pentecostal Commentary.)

Smith, T V 1985. Petrine controversies in early Christianity: Attitudes towards Peter in Christian writings of the first two centuries. Tübingen: Coronet Books.

Snyder, J I 1986. Promise of his coming: The eschatology of 2 Peter. San Mateo: Western Book Journal Press.

Soards, M L 1988. 1 Peter, 2 Peter, and Jude as evidence for a Petrine school. Aufstieg und Niedergang der römischen Welt (II 25.5), 3827-3849, Berlin: Walter de Gruyter.

Speyer, W 1977. Religiöse Pseudepigraphie und literarische Fälschung, in N Brox (Hrsg), Pseudepigraphie in der heidnischen und jüdischen-christlichen Antike, 195-263, Darmstadt: Wissenschaftliche Buchgesellschaft. (Wege der Forschung 484.)

Spicq, C1966. Les Épitres de Saint Pierre, Paris: Lecoffre, Gabalda.

Stauffer, E [1946]1948. Die Theologie des neuen Testaments.Gütersloh: Gütersloh Verlaghaus.

Sterling, G E 2005 The Jewish philosophy: The presence of Hellenistic philosophy in Jewish exegesis in the second temple period, in C Bakhos (ed), Ancient Judaism in its Hellenistic context, 131-154. Leiden: Brill. (Suppl to the Journal for the Study of Judaism 95.) 
Tromp, C J 2003. Origen on the 'Assumption of Moses', in Martinez, F G \& Luttikhuizen, G (ed), Jerusalem, Alexandria, Rome: Studies in ancient cultural interaction in honour of A Hilhorst, 323-340. Leiden: Brill.

Van Houwelingen, P H 1993. 2 Petrus en Judas: Testament in tweevoud. Kampen: Kok.

Van Tilborg, Sj 1996. Reading John in Ephesus. Leiden: Brill. 